\title{
Tourism Marketing Mix Applied for Inclusive Spiritual Tourists in Pakistan and Australia
}

\section{Page 30}

Received: 30 Oct 2020 Revised: 08 Jan 2021 Revised: 18 Feb 2021 Accepted: 13 Mar 2021

\section{NBR}

NUST Business Review (c) NUST Business School NBR-21010901

Vol. 02 (02)

12, 2020

pp. $30-46$

DOI:

This is an open access article under the CC BY license

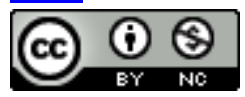

\author{
Dr. Farooq Haq, \\ Canadian University of Dubai, United Arab Emirates \\ Prof Dr John Jackson \\ Central Queensland University, Australia
}

\begin{abstract}
Purpose: The paper displays an exploratory research on marketing of spiritual tourism in Australia and Pakistan. The main objective of this research is to explain spiritual tourism and present elements of marketing mix for attracting spiritual tourists with inclusive attitude. The paper describes spiritual travellers with inclusivity going on journeys for spiritual enhancement and veneration for divine places of other faiths considered as holy sites.

Methodology: A qualitative study constructed on face-to-face interviews with tourists qualified as spiritual travellers was managed in selected Australian and Pakistani locations. The discussion notes were screened through theme-based assessment searching for ideas and themes surfacing from interviews aligned with elements of the marketing strategy.

Results: This study resulted in acknowledging people, pricing and products as vital elements of tourism marketing complementing the spiritual tourism marketing strategy design and implementation.

Conclusions: This study concludes with an inclusive spiritual tourism model indicating people, pricing and products to be embraced by tourism providers to enhance their marketing outcomes. This paper accomplishes by offering the recommendation for Pakistan's tourism administration to market holy and blessed places linked with different faiths following the branding theme of "spiritual tourism".

Future Direction: Tourism marketing mix based on people, pricing and products, could be analysed by a quantitative research testing inclusivity based behaviour of spiritual travellers.

Originality: The unique and primary study handled the threat of disinclination of tourists expressing their personal religious opinions through private meetings and face-to-face discussions.
\end{abstract}

Keywords: Product, Pricing, People, Spiritual tourism; Tourism, Spiritual tourism, Marketing mix, Qualitative,

Paper type: Research Paper 


\section{Key points}

1. The inevitability of utilizing face-to-face discussions in complex study topics such as spiritual tourism.

2. The imperative significance of clearly explained multi-religious traveling based on religious inclusivity in an unpredictable planet.

NBR

3. The growing magnitude and development of spiritual tourism around the world demands sharply designed strategy mix for its marketing as illustrated in the given model.

\section{Introduction}

The travel industry revolves around layers of services that exhibit unique characters in business and sociology (Jovicic, 2016; Norman, 2014). Among various types of tourism recognized by industry players and researchers, special interest tourism is defined as a unique kind of tourism offering specialized benefits such as augmentation, fortification and development of an individual (Lee and Bai, 2016; McKercher and Prideaux, 2014). The concept and practice of special interest tourism implies towards the growing branch of spiritual tourism, accepted as its subset that offers travel packages based on people, places and events for self-spiritual development (Haq, 2014; Clingingsmith, Kwaja and Kremer, 2009; Andriotis, 2009). The current publications on spiritual travel and journeys have indicated a shift from exclusive or self-preferred destinations to inclusive spiritual tourism based on various controllable and uncontrollable factors (Štefko, Királ'ová, and Mudrík, 2015; Olsen, 2013). Exclusive spiritual tourism could be closely mapped with religious tourism, since religious tourists travel for fulfilling the commandments of their formal faith, which is the key difference with spiritual tourism and inspires its customers (Egresi and Kara, 2016; Haq, 2014; Norman 2014).

Spiritual tourists were not recognized in this research paper because of their self-description or forced judgment by the authors, but due to the fact that respondents, calling themselves as Hajis, Yatris, or pilgrims, were excited and searching for personal spiritual enhancement or augmentation. The collaboration between major participants and stakeholders is essential in modern tourism marketing that facilitates the narrowing of travelers (Weidenfeld, 2018). The inclusive and exclusive nature of tourists is recognized by narrowing down of spiritual tourism consumers (Egresi and Kara, 2016; Clingingsmith, Kwaja and Kremer, 2009). The behavioural aspect of being inclusive is adopted to segregate spiritual tourists and sharpen the focus in this paper. Inclusive spiritual tourists are defined as those journeying to associate with God, while respecting other faiths and religious traditions, they also understood that all faiths point towards the way to God but through dissimilar practices and rituals (Haq and Wong, 2011).

As per the description given above, inclusive spiritual tourists were specified and contacted for this research in Australia and Pakistan. Their inimitable inclusive behaviour was reflected during discussions when participants indicated a global and natural demand for multi-faith consideration, mutual peace and social coherence. The meetings highlighted need for followers of different religions to socialize, understand and mutually gain from spiritual rituals and practices. This helped the aim of this study converging on the crafting of marketing strategies constructed upon the knowledge gained through direct discussions. Followers of various faiths known as Muslims, Christians, Jews, Buddhists, Hindus and Bahais revealed their inherent inclusive spiritual behaviour. Henceforth, the research 
appreciates inclusive spiritual tourists as travellers visiting revered, holy and divine destinations connected with faiths of others, with the purpose of respecting and studying other religious teachings and customs.

\section{Literature Review}

For a long time, humans around the world have been curious to learn

NBR about spirituality from religious and secular perspectives (Norman 2014; Olsen 2013; Cohen, 1972). Scholars agree that spirituality became a point of contention and discussion in research and business circles only in this century (Bowler, 2014; Clingingsmith, Kwaja and Kremer, 2009). With the rise of research interest in spirituality and tourism, marketing and business scholars also realized the potential of new knowledge and business strategy associated with spiritual tourism (Haq and Wong, 2011; Eid 2012). The discussion on literature is divided into two main areas integrated with this research. Firstly, the notion of spiritual tourism followed by the characteristics of inclusive spiritual tourists. Secondly, subject of tourism marketing holistically, and spiritual tourism marketing precisely.

\subsection{Spiritual Tourism}

Spiritual tourism, pilgrimage and religious tourism are motivated by faith and religion, academically they are accepted as subsets of special interest tourism and cultural travels Clingingsmith et al., 2009). Therefore, the point is still under argument that religious and spiritual tourism are different and cannot replace each other as supposed by different tourism business operators (Norman 2014; Olsen 2013; Cohen, 1972). Nevertheless, there is a significant resemblance between pilgrimage, religious tourism and spiritual tourism, that is the fact that they are amongst the earliest kinds of journeys associated with inner-faith providing comfort and inherent peace to the visitor (Bowler, 2014; Moal-Ulvoas and Taylor, 2014; Eid, 2012; Clingingsmith, Kwaja and Kremer, 2009). Among the earlier known researchers on religious tourism, Cohen (1972) explored different aspects of sacred and holy tourism; he concluded that the holy, sacred, religious and spiritual were various motivations for tourists seeking inner peace and self-development, largely embedded in formal religions.

The human thirst seeking logic and perseverance can be perceived as opportunities for many businesses. On the contrary, business theory cannot accept that there is One God and there are people who devoted their lives following the love and directions from the God (Bowler, 2014; Matheson, Rimmer and Tinsley, 2014). Cohen (1972) explained that spirituality without a formal belief can be described as a mystery that opens itself to people as an unseen strength that connect a person with him or herself. On the other hand, spirituality can be explained through a multi-faith dimension where it is seen as an individual, discrete and inner fact that is accepted as the centre of various belief traditions (Olsen, 2013; Nicholson, 1978). The renowned Sufi thinker Ibn Al-Arabi, recognized as the mystical teacher of Ertugral, the predecessor of the Usmaniyah Khilafat in Turkey, established a multi-religious understanding of spirituality in thirteenth century as: "my heart has become capable of every form: it is the pasture of gazelles and a covenant of Christian monks and a temple of idols and the pilgrim's Ka'ba (Makkah) and the tables of the Tora and the book of Quran. I follow the religion of love: whatever way love's camel takes, that is my religion and faith" (Nicholson, 1978, p.67). 
The subject of spirituality-based traveling has recently been discussed by researchers as a niche tourism segment. In order to apprehend the business and social meaning of spiritual tourism, the classification of a spiritual tourist could be followed as established by Haq and Jackson (2009, p. 145): "someone who visits a specific place out of his/her usual environment, with the intention of spiritual

NBR

2,2

Page 33 meaning and/or growth, without overt religious compulsion, which could be religious, non-religious, sacred or experiential in nature, but within a Divine context, regardless of the main reason for travelling". The definition of a spiritual tourist can be implied for spiritual tourism as a business and academic concept. The criteria of excluding any religious compulsion is mandatory to understand spiritual tourism as an individual experience gained from traveling. This classification identifies travellers journey to holy destinations and events searching for a Divine experience, without claiming to be devotees of any specific orthodox faith. Recent scholars in this area have agreed that various segments of tourists have been recognized, who include individuals known as inclusive spiritual tourists, for example members of the New Age groups, strictly claiming to be non-religious, while testifying that the central focus of their faith is God, Holy Spirit or a Super Being (Haq and Medhekar, 2017; Egresi and Kara, 2016; Štefko et al., 2015).

\subsection{Tourism Marketing}

Tourism products and services have been effectively marketed by government and private tourism agencies around the world. In 1990s, tourism became competitive with the rise of Asian destinations and tourism marketing was attracting travellers with new packages and competitive deals (Buhalis, 2000; Riege and Perry, 2000). The new and novel tourism packages interactively started offering a combination of people, places and events where several players with overlapping business interests were involved (Weidenfeld, 2018; Haq; 2014; McKercher and Prideaux, 2014). Nevertheless, researchers have raised concerns that regardless of surge in international tourism, the academic and business research conducted to support the development in marketing of tourism has been insufficient (Haq and Wong, 2011; Dev, Zhou, Brown and Agarwal, 2009; Buhalis, 2000). This fact identifies one of the justifications for conducting this research in a unique domain of tourism.

The tourism marketing has been appreciated as a global industry, but not a global research avenue due to pre-specified products and services and narrowed destinations and travellers. This research attempts to open to research venues towards a specialized tourism product that could be marketed in two different countries with different people and cultures. Primarily, researchers indicated that in the tourism industry; markets are classified into three classes: products offered, need fulfilment of tourists and traveller's personality (Dolnicar and Ring, 2014; Pike and Page, 2014; Buhalis, 2000). The Product cantered marketing emphasized on the fundamental description of the tourism product or service, which highlighted the core business of the tourism organization. The success in tourism marketing relied on the agency's competence to match the service offered with the core value pursued by the tourists (Mistilis, Buhalis and Gretzel, 2014; Dev, Zhou, Brown and Agarwal, 2009). Similarly, marketing based on need fulfilment focuses on the process of product delivery aiming at tourist's satisfaction while concentrating on developing and adopting a consumer perspective by the agency. 
NBR

2,2

Page 34

Tourism marketing based on traveller's personality highlighted the notion that different tourist segments represented different personalities with different preferences that could be analysed in specified groups (Dolnicar and Ring, 2014; Dev et al., 2009). The authors of this paper realized that inclusive spiritual tourists belonged to a special interest tourism background; therefore, the tourism marketing strategy was crafted in line with the personalities carrying preferences for their journeys.

Further exploration on publications related to tourism marketing indicate three critical orientations that have been adopted by marketers, they are: concentration on tourism consumers, competition among tourism providers and the trade related to the tourism industry (Riege and Perry, 2000). The marketing approach related to tourism consumers focused on single or group of travellers, their tastes, preferences and expectations. The marketing method related to competition among tourism providers focused on products and services offered by other tourism providers. The marketing attitude related to trade within and across the tourism industry, first concentrated on roles of various intermediating agencies involved in the tourism process.

The marketing approach related to tourism consumers is more applicable for spiritual tourism marketing as spiritual tourists as they carry distinctive and exclusive needs and demands. Moreover, marketing related to tourism consumers covers three core aspects essential to craft tourism marketing strategies, including: the traveller's emotional situation at the destination, earlier hopes from the destination, and the cognitive goal or purpose of gaining knowledge and fulfilment from the destination (Dolnicar and Ring, 2014; Riege and Perry, 2000). Based on the above discussion, the main goal of this paper is to suggest to differentiate the tourism product and service by enhancing its distinctiveness, and hence delivering the promise to fulfil the needs of a spiritual tourist, as outlined by other researchers in tourism marketing. (Haq, 2014; Eid, 2012; Buhalis, 2000).

The tourism marketing mix framework deliberated from Morrison (2002) was used in this research in order to achieve the marriage between the suggested spiritual tourism marketing strategies and relevant implementation in tourism markets across various geographical locations. The marketing theory is not built here but constructed and applied for a novel tourism product. Researchers in tourism marketing agree that the uncomplicatedness and result oriented application of the marketing mix framework enhances the credibility of adopting it for spiritual tourism marketing (Haq, 2014; Eid, 2012; Haq and Wong, 2011). Three critical elements of people, product and pricing are used in this paper adopted from the marketing mix of Morrison (2002). The justification of selecting the three elements of the tourism marketing mix is delivered below with reference to the current publications in the areas of tourism and marketing.

The offering presented to the spiritual tourist, including the packaged services is called as the product (Pike and Page, 2014). Similar to all products, the tourism product also goes between various stages of the product life cycle, which opens the debate between place marketing and tourism marketing. Where place marketing refers to marketing of the site or destination, the tourism marketing refers to all-inclusive elements of the tourism experience based on tourists' expectations and feedback (Pike and Page, 2014; Morrison, 2002). 
Therefore, all tourism marketers stress on delivering high quality service and delightful experience that must be essentially embedded with the tourism product (Pike and Page, 2014; Eid; 2012). Haq and Medhekar (2017) argued on similar grounds that the spiritual tourism product is not a new product, but with recent upsurge in spiritualty related topics, spiritual tourism product seems to be enjoying the growth stage in the life cycle.

Similar to general marketing, pricing plays an important role in tourism marketing as the only strategic option to earn revenue and profits for organizations

NBR

2,2

Page 35 (Mistilis, et al., 2014; Moal-Ulvoas and Taylor, 2014; Riege and Perry, 2000). Researchers in pilgrimage and religious tourism have indicated that tourists with such motivations do not worry much about the cost of services, yet, smart pricing of packages can attract more travellers and more regularly (Dolnicar and Ring, 2014; Eid, 2012; Haq and Wong, 2011). Different strategies for pricing have been presented in this paper that could be affectively adopted for agencies offering inclusive spiritual tourism products and services.

The last element of tourism marketing mix used in this paper is the performance of people involved in the tourism process. Tourism being primarily a service industry, the significance of people supporting the marketing plan is a key for the business success (Matheson et al. 2014; Egresi and Kara, 2016; Morrison, 2002; Buhalis, 2000). In a spiritual tourism process, various people such as booking agents, travel consultants and trip guides coordinate with travellers at different points before, during and after the visit (Egresi and Kara, 2016; Lee and Bai, 2016). People associated with inclusive spiritual tourists need to be equipped with understanding and knowledge of multi-religious spirituality, as tourists will be expecting to learn and experience spiritual experience from multi-faith treasures of peace and tranquillity. Therefore, the training and recruitment of the 'people' involved with inclusive spiritual tourism has to be marketing oriented rather than profit oriented (Haq and Wong, 2011).

\section{Methodology}

The qualitative methodology was adopted for this paper because of the exploratory character of the study conducted on marketing inclusive spiritual tourism (Huberman and Miles, 2002). This qualitative research embraced critical realism as the ontological basis to analyse the data collected from the interviews since the views and opinions on spirituality are very broad and any interpretation could result in subjective analysis. Critical realism supports the research issue that while there are several viewpoints and realities perceived by the researcher and participants, the researcher is obligated to have an objective and critical stance to reach new knowledge by enhancing the impartiality and transparency within the research process (Lincoln, Lynham, and Guba, 2011). Moreover, since spiritual tourists were expected to share their personal beliefs and practices linked to their spiritual rituals, hence critical realism was the best option to objectively record and assess their statements and perspectives.

\subsection{Research Objectives}

The core research objective for this paper was embedded in the question: 'what are the elements of the marketing mix that could be adopted for the marketing of inclusive spiritual tourism'? This research objective was managed by asking and prudently searching following four questions, used as pointers to collect data for this paper, from Australian and Pakistani spiritual tourists: 
1. What makes you define yourself as a spiritual tourist, justify please.

2. Which factors inspire you for spiritual tourism, do you think religion is among the factors?

3. Being a spiritual tourist, do you visit holy destinations and religious events associated with your own faith only, or other faiths as well, please further describe your thoughts?

4. Based on your understanding, among places, promotion, people, products and pricing,

NBR

2,2

Page 36 which aspects of marketing for spiritual tourism are more significant to you: please further describe your opinions?

Each interview's discussions were managed by writing notes since participants expressed discomfort to have audio recording of their discussion on individual beliefs and views associated with spirituality. All interviews in Australia were conducted in English, whereas, in Pakistan, English and Urdu languages were used to communicate with participants. The interview transcripts were read several times individually by both authors obeying the thematic analysis (Zhu, Duncan, and Tucker, 2019). Both authors independently tried to specify ideas of individuals associated with the argument on market strategy for inclusive spiritual tourism. Since all participants were selected through a sampling qualification process, both researchers assessed each tourist and decided about their qualification for this study, hence convenient and purposeful sampling method was utilized (Lincoln et al., 2011; Miles and Huberman, 2002).

\subsection{Data Collection and Coding}

Based on the convenient and purposeful sampling method discussed above, this research study consisted of qualified twenty-nine spiritual tourists from Australia and thirty-two from Pakistan. Although seventy-six participants were booked for direct interviews, sixty-one were available who eventually participated in interviews. The data collection process was completed when the team of authors agreed during the data collection process that sixty-one interviews were sufficient for the knowledge saturation and hence research qualitative isomorph was accomplished (Lincoln et al., 2011; Miles and Huberman, 2002).

The interviews were conducted with spiritual tourists in Australia in these cities: Sydney, Darwin, Brisbane, Maleny, Canberra, Melbourne, Cairns and Rockhampton. The spiritual tourists in Pakistan were queried in these cities: Karachi, Taxila, Lahore, Islamabad, Lahore, Multan, Okara, and Swat. As mentioned, all participants were first inquired to confirm that they were eligible to be inclusive spiritual tourists, then research questions were used to have detailed discussions for insights into their understanding and perspectives.

The face-to-face meetings and the emerging discussion with travellers belonging to the two nations revealed noticeable comprehensions about their spiritual journeys. Both authors reviewed all copies of discussions repeatedly by following the thematic analysis while searching for credible statements expressed in interviews as perceptions and quotes delivered by respondents (Zhu et al., 2019; Yin, 2017). Following procedures prescribed by Miles and Huberman (2002), the qualitative data received from interviews in each country was processed through primary coding based on the transcripts that was written and finalized after each meeting. Subsequently, on each interview transcript, both authors wrote memos in different colours as key words or ideas recognized from the interview that could be further utilized in creating and building the research themes. 
The spiritual tourists in Australia were met for interview discussions by both authors in their university offices, homes, during university conferences, at International Mosque Days organized by Islamic Associations in Islamic Centres of Darwin and Rockhampton, and in Maleny during the National Spiritual Multi-

NBR

2,2

Page 37 Faith Event. The spiritual tourists in Pakistan were met for interview discussions by an author in their homes or offices, at popular Mausoleums of renowned Sufis and also, some excited participants came to Islamabad to the residence of the author residing there temporarily. The time duration of discussions varied from 30 to 60 minutes. At the end of the interview, the author or authors would confirm the dominant quotes delivered by the respondent, in some cases, respondents were reached via telephone or emailed the dominant quotes in order to confirm that authors had received and recorded the statements accurately.

\section{Findings}

The sixty-one participants recognized by both authors as inclusive spiritual tourists, qualifying as per the present criteria, were followers of different faith traditions, including: Islam, Christianity, Muslim, Hinduism, Buddhism, Sikhism and Baha'ism. It has been specified in this paper that those inclusive spiritual tourists were qualified for this research who expressed their willingness to travel to sacred, spiritual, religious and divine destinations associated with other faiths. Their purpose to travel as spiritual tourists was to experience and learn the spiritual traditions, knowledge, history, rituals and worship methods of diverse faith for their own spiritual development.

The question numbers 1 , and 3 were used to assess and confirm that the participant was an inclusive spiritual tourist. The findings from these two questions also provided support to build the theory in spiritual tourism and its construct the domain of inclusiveness. Question numbers 2 and 4 were focused towards crafting the marketing mix strategy elements, which supported the theory building for spiritual tourism marketing, this is explained in details in the subsequent discussion of this paper.

It was observed that respondents who were already qualified as inclusive spiritual tourists were clear about their stance on multi-faith spirituality and all of them advocated for a global need to harmonize spirituality based on diversified religious backgrounds. Respondents in both countries were found to be stressing upon the need for global seminars, festivals and events where people with similar thoughts and believers in inclusive spirituality could meet, socialize and learn different types and forms of spiritual customs and rituals.

The inclusive spiritual tourists in Pakistan repeatedly stated that they were against religious fundamentalism and grouping that destroyed the Pakistani economy and the social harmony. Respondents expressed frustration from global trends towards religious extremism and exclusivity that could be managed by direct communications between leaders and followers of all faiths around the world. The fear of the unknown was also mentioned as a threat not only to global peace but also an eminent enemy of the Pakistanis regularly used by religious factions and sectarianism. It was noted that inclusive Pakistani spiritual tourists venerated and admired other faiths and had impressive knowledge about their spiritual traditions. 
Most Pakistanis interviewed were keen to travel to sacred sites associated with other faiths and to participate in their traditions and customs. This religious inclusiveness was expressed by many Muslim respondents as a basic tenant of their understanding of the principles of Islam, to socialize with nonMuslims and exchange the spiritual knowledge. As an example, some Pakistani inclusive spiritual tourists narrated their journeys to the religious sites associated

NBR

2,2

Page 38 with Hinduism and Sikhism in Lahore, and cherishing the fact that some past Muslim rulers were spiritually enlightened and intensively committed and devoted to guard and rebuild holy and spiritual monuments belonging to Hindus and Sikhs.

The inclusive spiritual tourists in Australia referred to various multifaith events and gatherings that have been attracting masses from around the continent. Every year, Maleny in Sunshine Coast organizes the National MultiFaith Festival. This event is planned and presented as a multi-religious and inclusive festival where thousands of inclusive spiritual tourists gather for three days and share their spiritual treasures. Various religious organizations such as Christian, Islamic, Buddhist, Hindu and Jewish; organize their own cultural, food and educational stalls. The Multi-Faith Festival also sets various venues for presentations from various religions on certain common spiritual topics, such as: faith and humanity, religion and family life, faith and environmentalism or religion and governance. In recent years, various Australian cities have started organizing similar events to attract people looking for spiritual development and multi-cultural harmony. Some travel agents are offering inclusive spiritual tourism packages to individuals and groups to attend these Multi-Faith Festivals in different cities with the aim to offer pluralistic and multi-religious spiritual exchange.

The marketing success of any type of tourism, especially spiritual tourism depends on the branding approach adopted by the providers. In case of inclusive spiritual tourism, multi-faith harmony and love needs to be used to brand the relevant products and services. Furthermore, any overtly uni-religious names, labels and symbols shall be avoided to show disconnect with any specific religious traditions. As an example, during the fund raising for a new Mosque, the word Mosque or Muslim Worship House can be avoided. Hence, using a theme as 'Fund raising BBQ for Darwin Mosque' could be replaced by 'Fund raising BBQ for Islamic Spiritual Centre in Darwin'.

Similarly, promoting events in Churches and Mosques where people from other religions are openly invited, message of openness and sincerity will be more successful. Majority of Muslim participants indicated that the annual Open Days arranged in various Mosques in Australia were fruitful since they were branded as Open Days, with the message of inclusiveness and hospitality. Likewise, few Christian participants mentioned that the visit of the Pope Benedict XVI to Sydney in July 2008 was branded as 'World Youth Day', with the core purpose to attract inclusive spiritual tourists from different religious backgrounds throughout Australia.

The inclusive spiritual tourists from both countries mentioned that a combination of religious symbols and sacred names, icons and sites among religions is another approach used for implying inclusivity in spirituality. 
For instance, inclusive spiritual tourists in Pakistan mentioned that Pakistan is a location where all faiths have been permitted and accepted to be practiced and were promoted with love and sincerity for centuries, but due to few unfortunate events, global media has been portraying the country as unsafe and unwarranted for people believing in religions other than Islam.

The opening of the Kartarpur Gurdwara in November 2019, a Sikh Temple, which allows a visa free corridor for Indian spiritual tourists to enter Pakistan and visit the Gurdwara is an example of the Pakistani people and their

NBR

2,2

Page 39 support for inclusive spirituality. Likewise, Pakistan contains the pre-historic Buddhist hermitage in a place called as Takhte Bahi, the relics of Buddha in the Swat valley in Pakistan fascinate many Buddhist and non-Buddhist inclusive spiritual tourists. These sites need inclusive marketing messages with new campaigns branded as 'Spiritual destinations for spiritual visitors'. A similar strategy of combining multi-faith spiritual branding has been used in Australia. The Australian respondents elaborated that the Mosque located in Melbourne enjoys large numbers of visitors on its Open Day and other public events since the registered name or brand used for the Mosque is very inclusive: 'Virgin Mary Mosque'.

\section{Discussion and Implications}

The preceding section presented findings that were extracted from the discussion with participants constructed on their responses for the four research questions. The deliberation of inclusive spiritual tourists for question numbers 2 and 4 illustrated that they perceived people, product/service and prices to be clearly mapped with the probable crafting of a marketing strategy. Therefore, product, people and pricing from the tourism marketing mix, are applied to present the marketing strategy for inclusive spiritual tourism, which is a unique contribution to tourism knowledge, which explains the theoretical and managerial implications of this research in the following.

\subsection{Product based Marketing}

Although Australia is known to be among the top 5 global tourism destinations, yet it does not possess any recognized inclusive spiritual places on the global tourism map. It is interesting to note that some Australian respondents mentioned that they believed few sites in Australia were religiously inclusive since they were perceived inclusive by many religious people. Examples for such inclusive spiritual places quoted by respondents included: the shrine of the Roman Catholic Nun Mary MacKillop who was beautified in Sydney, the parish of Saint Teresa in Northern Territory, The Worship Centre of Baha'i faith near Sydney, Fo Guang Shan Nan Tien Temple in New South Wales. These places are always open to travellers from different religions and many visitors claim inclusive spiritual experiences in these destinations.

This research suggests that such places, including more spiritual sites could be discovered, and requires a different marketing approach. These places could be marketed or rebranded as spiritual tourism sites targeting inclusive spiritual tourists from Australia and overseas. Hence, regarding the product strategy, Australia does not require an inclusive spiritual tourism physical site, since the spiritual experience of the place is more important that the material structure. 
Moreover, the inclusivity of the place could be enriched by strong digital marketing based on social media apps where organizers and visitors can effectively communicate about the programs, services, experiences and further improvements. It was observed from interviews in both countries that inclusive spiritual tourism based conferences, seminars and other events are being organized and their popularity is on the rise. However, the recent health threat of COVID-19 has damaged the tourism market. Otherwise, social and religious groups have been active in organizing events that create the product for inclusive

NBR

2,2

Page 40 spiritual tourism. For instance, the Australian Sufi Centre organizes various seminars and symposiums that attract large numbers of inclusive spiritual tourists. International Sufi Symposium named as Moulana Rumi and the Perfume of Divine Love, was very successful for the like-minded organizers and attendees. Similarly, the National Sufi Seminar, arranged regularly in Lahore and the International Conference on Guru Nanak Heritage of Interfaith Understanding for Harmony and Peace were well received by the audience in Pakistan.

Event organizers can use this discussion to market their seminars and symposiums as spiritually inclusive rather than for a limited audience of religiously exclusive attendees. In Pakistan, some events like these are even targeting attendees from a particular sect that makes it more exclusive and risky to manage. For the market expansion, the range of customers could be improved by designing and presenting such programs as more inclusive and welcoming to all people, which could be from different religions or sects. Likewise, selected religious places could be redesigned, presented and marketed as open places to attract open-minded travellers.

Furthermore, advertisement posters can be very tactically worded in order to underline the inclusivity phases. Sometimes an unwitty idea related to words, even with a positive meaning for followers, could end up messing the complete market plan. Relatedly, the sentimental excitement to invite new colleagues must be managed with restraints to avoid the mismatch with the inclusive spiritual tourism product and service.

\subsection{Pricing based Marketing}

Due to the unique tastes and preferences of inclusive spiritual tourists, the discriminatory pricing strategy is suggested to be more applicable. This research also advocates that the size of inclusive spiritual tourism is growing with more awareness and communications, hence targeted or niche pricing may not a sustainable choice for tourism providers. Pakistan seems to be a uni-faith country with a Muslim majority, but the Muslim groups are further divided into uncountable sects where the inclusiveness needs to be applied under on religion of Islam.

Australia is well known as a pluralist and multi-cultural country with followers from many different religions. As informed by respondents in this research, the relationship among various faiths is improving and people are more informed and welcoming about others' religions. The inclusive spiritual tourism and other related businesses are growing and many new types of products and services are emerging within this market. Hence, the discriminatory pricing seems more congruent that can increase the loyal visitors, enabling businesses to offer range of prices to inclusive spiritual travellers mapped with customized packages. 
NBR

2,2

Page 41

The major contrast between Australian and Pakistani spiritual tourists was that Australians behaved more price consciously about their spiritual tourism choices. Pakistani spiritual tourists expressed less concern over prices, though they preferred to primarily visit spiritual places and events associated with Islam. Visiting sacred and holy places of other religions was their secondary choice, which still keeps them in the inclusive behaviour but with own-religion as the major preference.

The current tourism crisis due to COVID-19 and weakening Australian dollar has damaged outbound tourism, hence local tourism agencies need to focus and design their packages with inclusive spirituality as a new way of branding. Moreover, various Australian respondents stated that the global issues and personal problems inspired them for spiritual tourism hence they were seeking medium priced packages. The religiously diverse society of Australia could be utilized by tourism providers by aligning with management of different spiritual sites. Likewise, the unstable political and public safety issues have halted any inbound international tourism in Pakistan, hence local inclusive spiritual tourists can be attracted towards spiritual tourism products and services strategically marketed by government and private tourism providers.

Another implication for tourism operators is to consider personal and group tourism options implying the need for pricing strategically for personal or group-based spiritual tourists. Moreover, discounts could be offered to bigger groups who are aligned with certain religious or spiritual organizations, as another example of discriminatory pricing.

The research also revealed a general temptation where tourism operators tend to demand for more money from overseas travellers. Some tourism organizations consider this an effective price differentiation strategy making higher profits. However, such places marketed as inclusive spiritual tourism loose customers and markets because of unfairly high and non-spiritual prices.

\subsection{People based Marketing}

People play a dominant role in tourism marketing and their dominance is increasing in the modern tourism industry (Dolnicar and Ring, 2014; Dev et al., 2009; Morrison; 2002). Most inclusive Australian spiritual tourists expressed their preference to communicate with people who were spiritually inclusive like them during their spiritual adventures. Similarly, inclusive spiritual tourists in Pakistani also desired to connect with people during spiritual tourism who were religiously inclusive. Hence, tourism providers need to consider the fact that the success of their spiritual tourism marketing, entrenched with targeting inclusive tourists, can only depend on inclusive people, tactically selected and trained, to operate during the tourism process.

As discussed, tourism marketing relies heavily on the people factor for any type of tourism. Since inclusive spiritual tourism is highly specialized, hence the role of people becomes more decisive. It implies that the challenge of finding right people for inclusive spiritual tourism also complicates the marketing process. The right person cannot be faked by dressing in a 'spiritual' sense or merely by speaking a religious language, it has to be the complete spiritual personality engaged with tourists during the adventure. 
NBR

2,2

Page 42

Figure 1:

Inclusive

Spiritual Tourism

Model
The inclusive spiritual tourists interviewed in Australia and Pakistan expressed various narratives about facing different people who were not rightly selected for the inclusive spiritual tourism. Some inclusive spiritual tourists in Australian expressed grief when during certain Mosques' Open Days or other multi-religious events, the host was unable to present the real inclusiveness from his or her own behaviour. Some Muslim tourists accidently bumped into religious fanatics during their visits to certain Sufi shrines, who started lecturing and forbidding them from visiting the graves with the warning as if they were glorifying the dead, an act against Islamic principles. As an example, a Pakistani spiritual tourist had a clash with a bus driver in Pakistan while traveling to the Panja Sahib Shrine that is very revered by the followers of Sikhism. The driver of the bus was abusing the spiritual tourist and threatening him not to go to the Sikh Shrine as he equated the visit to renouncing the Islamic faith. The discussion on the findings given above, concludes with an Inclusive Spiritual Tourism Model given below.

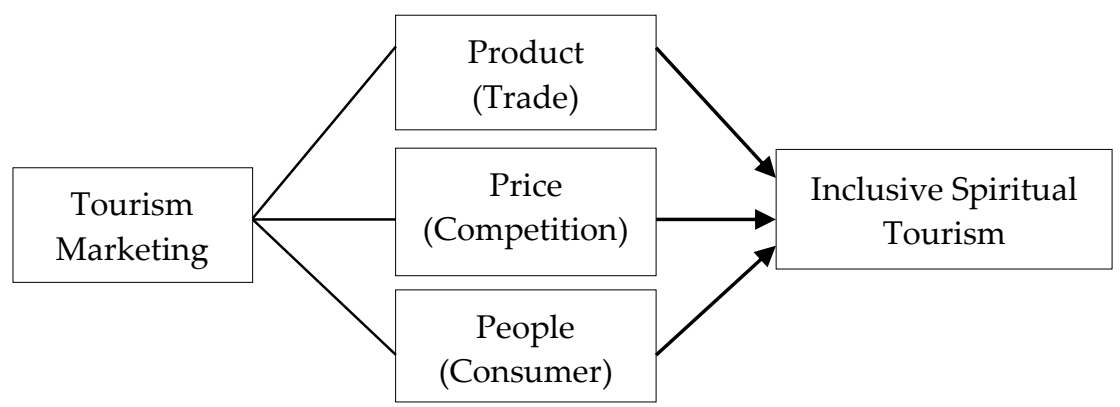

\section{Conclusion and Future Research}

The analysis of interviews conducted with respondents in Australia and Pakistan indicate that effective marketing of inclusive spiritual tourism needs to be based on positioning spiritual tourism, which is constructed on the differentiation of the offered products and services. To achieve the market differentiation of spiritual tourism product, inclusive spiritual tourists must be sharply identified and segmented. The three elements of the tourism marketing mix: product, pricing and people were selected due to their mapping with the ideas emerging from all interviews. The product, pricing and people could also be applied to implement the differentiation marketing strategy focusing on inclusive spiritual tourists as illustrated in Figure 1.

This research illustrated the business application of the elements of the marketing mix strategy for the inclusive spiritual tourism market. The final sample of sixty-one participants in Australia and Pakistan implied that tourism marketers must be tactical to interpret that the spiritual tourism market in both countries included majority of spiritual tourists who were behaviourally more inclusive. A future study using quantitative methodology could be used to verify this domination of inclusive spiritual tourists, though this study confirms that it is important and viable to craft a tourism marketing strategy focusing on inclusive spiritual tourists. 
NBR

2,2

Page 43

This paper concludes that the marketing strategy could be applied by using tourism marketing mix elements of product, pricing and people, to elaborate the implementation of the strategy. Moreover, such sharply crafted marketing strategy needs to be directed towards promoting places or events that received tourists from all religions and the message of multi-faith spirituality was openly communicated. This study also concludes that inclusive spiritual tourists are generally inspired by spiritual comprehension and understanding, mostly delivered by individuals who promote brotherhood of all souls, the inclusivity of God or a Supreme Being and open-to-all spiritual rituals.

Moreover, inclusive spiritual tourism has been observed to be gaining popularity in modern world that is more stressful and segregated. Most religions are united on the major rule of "treat other people as you would like to be treated", hence all people working for spiritual tourism must be trained under this policy of treating all in the best possible way. Comparably, spiritual tourism shall be marketed by promoting the common belief in people, love, relatives, the environment, harmony, aesthetics, nature and music. Meanwhile, marketing of spiritual tourism needs to be separated from exclusive and dividing philosophies followed by people and individuals in various countries around the world.

On a final note, this study provides a recommendation for the current Pakistani government appreciated for realigning the business lens towards international tourism constructed on religious, cultural and archaeological places. The modern tourism marketing has been refreshed by the Government of Pakistan by promoting national tourism targeting travellers with religious commitments who could be Sikh, Hindu or Buddhist devotees. Nevertheless, the "religious tourism" branding being adopted by the government is argued by this paper as not effective and not mapped with the international travellers' attitudes and behaviour. The branding based on "religion" is found in the marketing world to be redundant, cliché, unattractive, and hence repulsive. This study supports the shift towards innovative branding of the new brand of "spiritual tourism", either exclusive or inclusive, which will result in inviting and welcoming single and group tourists from different religions and nationalities to Pakistani destinations with the purpose of spiritual enhancement.

A study constructed on quantitative research could be used in the future to enumerate the results presented in this paper. The significant and challenging parallels need to be further studied, which could be explored by redesigning faceto-face discussion with travellers. Quantitative tools with a positivist ontology to collect and analyse data related to tastes and preferences of inclusive spiritual tourists is a probable augmentation of this study. The prequalified spiritual travellers could be approached in different countries and asked to participate by filling live or online survey questionnaires highlighting their tastes and inclinations for selecting spiritual tourism places and get-togethers.

The organizations and agencies providing services in spiritual tourism industry can be covered in a future research to analyse the business assessment, planning and execution of tourism products and services. Different government employees working for tourism in Pakistan, at various levels, could be invited for interviews and focus groups. Such meetings will provide comprehensions about the vision of the government regarding developing tourism in Pakistan, especially in the field of spiritual tourism. 
Finally, the government planners need to be persuaded and convinced that Pakistan can present a success story in special interest tourism with the brand of "spiritual tourism", and not religious tourism.

\section{References}

Andriotis, K., 2009. Sacred site experience: A phenomenological study. Annals of Tourism Research. 36(1), 64-84.

NBR

2,2

\section{Page 44}

Bowler, B., 2014. How Spiritual Tourism Might Change the World. The Huffinton Post, 2, p.13.

Buhalis, D., 2000. Marketing the competitive destination of the future. Tourism Management, 21(1), pp.97-116.

Clingingsmith, D., Khwaja, A. I., and Kremer, M., 2009. Estimating the impact of the Hajj: religion and tolerance in Islam's global gathering. The Quarterly Journal of Economics. 124(3), 1133-1170.

Cohen, E., 1972. Towards a sociology of international tourism. Social Research. 39(1), pp.164-82.

Dev, C. Zhou, K. Z., Brown, J. and Agarwal, S., 2009. Customer orientation or competitor orientation, Cornell Hospitality Quarterly, 50(1), pp.19-28.

Dolnicar, S. and Ring, A., 2014. Tourism marketing research: Past, present and future. Annals of Tourism Research, 47(1), pp.31-47.

Egresi, I.O. and Kara, F., 2016. Residents' attitudes to tourists visiting their mosques: a case study from Istanbul, Turkey. Journal of Tourism and Cultural Change, 16(1), pp.1-21.

Eid, R., 2012. Towards a high-quality religious tourism marketing: The case of Hajj service in Saudi Arabia. Tourism Analysis, 17(4), pp.509-522.

Haq, F. and Medhekar, A., 2017. Is Spiritual Tourism an Innovation in Tourism for India and Pakistan? In Leadership, Innovation and Entrepreneurship as Driving Forces of the Global Economy (pp. 519529). Springer International Publishing: New York.

Haq, F., 2014. The significance of partnership as a marketing strategy for Islamic spiritual tourism. Journal of Islamic Marketing, 5(2), pp.258272.

Haq, F. and Wong, H.Y., 2011. Exploring marketing strategies for Islamic spiritual tourism. Handbook of Islamic Marketing, Edited by Sandikci, O. \& Rice, G. pp. 319-337 Edward Elgar Publishing Ltd.: London.

Haq, F. and Jackson, J., 2009. Spiritual journey to Hajj: Australian and Pakistani experience and expectations. Journal of Management, Spirituality and Religion, 6(2), pp.141-156.

Jovicic, D., 2016. Cultural tourism in the context of relations between mass and alternative tourism. Current Issues in Tourism, 19(6), pp.605-612.

Lee, S. and Bai, B., 2016. Influence of popular culture on special interest tourists' destination image. Tourism Management, 52(1), pp.161-169. 
Lincoln, Y.S., Lynham, S.A. and Guba, E.G., 2011. Paradigmatic controversies, contradictions, and emerging confluences, revisited. The Sage Handbook of Qualitative Research, 4, pp.97-128, Sage Publications: New York.

NBR

2,2

Page 45
Matheson, C.M., Rimmer, R. and Tinsley, R., 2014. Spiritual attitudes and visitor motivations at the Beltane Fire Festival, Edinburgh. Tourism management, 44(1), pp.16-33.

McKercher, B. and Prideaux, B., 2014. Academic myths of tourism. Annals of Tourism Research, 46(1), pp.16-28.

Miles, M.B. and Huberman, A.M., 2002. The qualitative researcher's companion. Sage Publications: California.

Mistilis, N., Buhalis, D. and Gretzel, U., 2014. Future eDestination marketing: perspective of an Australian tourism stakeholder network. Journal of Travel Research, 53(6), pp.778-790.

Moal-Ulvoas, G. and Taylor, V.A., 2014. The spiritual benefits of travel for senior tourists. Journal of Consumer Behaviour, 13(6), pp.453-462.

Morrison, A. M., 2002. Hospitality and Travel Marketing, 3rd ed. Delmar Thomson Learning: New York.

Nicholson, R. A. (1978), The Tarjuman al-Ashwaq: A Collection of Mystical Odes by Ibn Al-Arabi, translated from original, Theosophical Publishing House: London.

Norman, A., 2014. The varieties of the spiritual tourist experience. Literature \& Aesthetics, 22(1), pp. 20-37.

Olsen, D. H., 2013. A scalar comparison of motivations and expectations of experience within the religious tourism market. International Journal of Religious Tourism and Pilgrimage, 1(1), pp.41-56.

Pike, S. and Page, S.J., 2014. Destination Marketing Organizations and destination marketing: A narrative analysis of the literature. Tourism Management, 41(1), pp.202-227.

Riege, A. M. and Perry, C., 2000. National marketing strategies in international travel and tourism. European Journal of Marketing, 34(11/12), pp. 1290-1305.

Štefko, R., Királová, A., \& Mudrík, M., 2015. Strategic marketing communication in pilgrimage tourism. Procedia-Social and Behavioral Sciences, 175(12), pp.423-430.

Weidenfeld, A. 2018. Tourism diversification and its implications for smart specialization, Sustainability, 10(2), pp. 319-343.

Yin, R.K., 2017. Case study research and applications: Design and methods. Sage publications: California.

Zhu, H., Duncan, T., \& Tucker, H. 2019. The issue of translation during thematic analysis in a tourism research context. Current Issues in Tourism, 22(4), 415-419. 


\section{About the Author:}

NBR

\section{Dr. Farooq Haq}

Dr. Haq holds a PhD in Marketing from Charles Darwin University, Darwin and an MBA in Marketing from Central Queensland University, Rockhampton, Australia. Dr Haq is considered as a pioneer of research in Marketing Spiritual Tourism and a recognized expert of Islamic Marketing. Since 2016, he has been a member of the Editorial Board for the Journal of Islamic Marketing, Emerald, Scopus listed and the Journal of Management and Research.

Dr. John Jackson

Professor at Central Queensland University, Australia

The Corresponding Author Dr Farooq Haq can be contacted at: farooq@cud.ac.ae 
